\title{
Identifying keystone predators and the importance of preserving functional diversity in sublittoral rocky-bottom areas
}

\author{
Sabrina Clemente ${ }^{1,2, *}$, José Carlos Hernández ${ }^{1,2}$, Adriana Rodríguez ${ }^{1}$, \\ Alberto Brito ${ }^{1}$ \\ ${ }^{1}$ Biodiversidad, Ecología Marina y Conservación, Departamento de Biología Animal (Ciencias Marinas), \\ Facultad de Biología, Universidad de La Laguna. Avenida Francisco Sánchez s/n, 38206 La Laguna, Tenerife, \\ Islas Canarias, Spain
}

${ }^{2}$ Present address: Villanova University, Biology Department, 800 Lancaster Ave., Villanova, 19085 Pennsylvania, USA

\begin{abstract}
Understanding the role of predatory fish within a community is essential to predict how ecosystem structure and function may respond to loss of fish species and to ensure conservation strategies are effective. The aim of the present study was to characterize relationships between predatory fish assemblages, sea urchin abundances and ecosystem function and services. By means of diet analyses and direct observations in the field, we identified key fish species with the potential to control the herbivore Diadema aff. antillarum and hence preserve fishing resources and coastal productivity in sublittoral rocky reefs around the Canary Islands. Differences in the composition and relative importance of predatory assemblages were observed along a gradient of fishing intensities comprising highly fished, lesser fished and marine protected areas. Increased fishing activity was associated with lower fish predator richness and higher urchin density. Most measures of predatory performance (frequency of predation, ingestion time, urchin size selection) differed between predatory fish species, showing that most predators of Diadema aff. antillarum are not functionally similar. This level of functional variation highlights the relevance of predator richness in controlling sea urchin populations. Depletion in species diversity leads to a loss of functional roles and cascading effects that may constrain ecosystem processes.
\end{abstract}

KEY WORDS: Diadema aff. antillarum · Top-down control · Functional diversity · Ecosystem function · Ecosystem service $\cdot$ Fishing resources

\section{INTRODUCTION}

One key issue in conservation ecology is the extent to which biodiversity and species conservation enforces the protection of ecosystem functioning and services. Well-characterized relationships between species identity, biodiversity and ecosystem function are crucial for predicting the ecological and economic impacts of human activities (Armsworth et al. 2007).

Fishing activities heavily target high-level marine predators (Pauly et al. 1998, Jackson et al. 2001), whose abundances have been reduced by up to an order of magnitude over the last decades, triggering community-wide changes (Steneck 1998, Myers \& Worm 2003). The removal of predators has been reported to cause substantial reductions in diversity and even local or global extinctions of target species (Pauly et al. 1998, Jackson et al. 2001). Entire functional groups can be removed from communities strongly impacted by fishing, resulting in impairment of important ecosystem functions (Holmlund \& Hammer 1999). Protecting ecosystem processes is imperative not only to conserve the system, but also to maintain the subset of ecological functions that are directly 
relevant to humans and provide valuable services (De Groot et al. 2002, Worm et al. 2006).

Predators can have indirect impacts on community organization whenever their prey strongly interact with other species, thereby extending the effect of the predator to the entire ecosystem through 'trophic cascades' (Paine 1980). In many benthic coastal ecosystems sea urchin grazing is a major determinant of plant community structure and organization, driving the transition from erect macroalgal beds to encrusting coralline barren grounds (Sala et al. 1998, Tegner \& Dayton 2000). The increase in fishing pressure has been linked to the expansion of sea urchin populations that, released from predation control, overfeed on macroalgae, causing the establishment of barren grounds at various latitudes (McClanahan \& Muthiga 1989, Sala \& Zabala 1996, McClanahan 2000, Tegner \& Dayton 2000, Guidetti 2004). These complex relationships highlight the functional importance of urchin predators in controlling the structure of entire communities on rocky substrates (Tegner \& Dayton 2000). It is critical to identify this predatory guild and study the implications of its diversity to enable a more general understanding of the ways in which predators can affect system structure and ensure that future marine ecosystem conservation and management policies are effective (McClanahan 1995).

In subtropical regions of the Canarian Archipelago, as well as in other Macaronesian areas, macroalgal beds are the main habitat-forming species at subtidal reef habitats. However, barren grounds generated by the sea urchin Diadema aff. antillarum are increasingly common (Hernández et al. 2008a), and their perseverance is thought to be one symptom of intensive overfishing (Bas et al. 1995, Tuya et al. 2006, Hernández et al. 2008a). Barrens result in a further decrease in regional productivity, including depletion in the fish communities in line with the global trend (Worm et al. 2006). Knowledge of sea urchin predators and their patterns of diversity is poor in the eastern Atlantic and additional research on this functional group is required before they can be considered in the practise of conservation. Relationships must be well characterized between fish assemblages and ecosystem functioning to facilitate the assessment and prediction of the ecological and economic impacts of human activities and of any changes in species composition (Armsworth et al. 2007). The present study has been directed towards understanding the role of fish predation in sublittoral rocky areas of the Canary Islands and expanding knowledge of the ecological importance of macrobenthic feeding species in relation to the consequences of their reduced populations in human-dominated ecosystems. We (1) identified key species or functional guilds with the potential to predate upon the sea ur- chin $D$. aff. antillarum; (2) tested the role of predators on sea urchin abundances and, indirectly, on the enhancement of locally valuable fishing resources; (3) evaluated whether different predatory guilds have different effects on the system; and (4) assessed the spatial scales relevant to both urchins and predatory fish assemblages within a framework of human activities.

\section{MATERIALS AND METHODS}

Predation observations. Day-time observations were made while SCUBA-diving between October 2006 and February 2007 at 3 coastal areas within the Canary Islands: La Restinga-Mar de Las Calmas marine protected area (MPA) and the nearby fished areas (FA) of El Hierro, and the highly fished areas (HFA) of Tenerife (Fig. 1). The high density and large mean size of predatory fishes at the MPA (Bortone et al. 1991, Tuya et al. 2004) was expected to facilitate observations of predation. The HFA in Tenerife was chosen due to the high abundance of juvenile urchins of $<2 \mathrm{~cm}$ test diameter (TD) found in barrens, enabling identification of fish species that prey on juveniles.

A total of 586 Diadema aff. antillarum individuals (456 adults \& 130 juveniles) were collected at study sites or nearby areas, and no damaged urchins were used for observations. Individuals were measured and assigned to 5 size class categories based on TD: (1) $<1 \mathrm{~cm}(\mathrm{n}=62)$, (2) $1-2 \mathrm{~cm}(\mathrm{n}=68),(3) 2-3 \mathrm{~cm}(\mathrm{n}=152)$, (4) 3-4 cm ( $\mathrm{n}=152)$ and (5) $4-5 \mathrm{~cm}(\mathrm{n}=152)$. From each size category, 2 urchins including juveniles where available, were placed in a natural position with the oral side on the rocky substratum, at a depth from 5 to $20 \mathrm{~m}$. An observer, located from 5 to $10 \mathrm{~m}$ away (McClanahan 1995, Sala 1997, Guidetti 2004), recorded the number and size of urchins preyed upon in $20 \mathrm{~min}$. At each site, 3 to 4 replicates of this procedure were conducted by 2 observers located sufficiently far apart so that they did not interfere with one and another. Fish species and numbers were recorded, assigning them to 1 of the 3 consumer categories (McClanahan 1995): (1) predator guild-species that break open the sea urchin test, (2) attempted predators - species that bite but fail to open the test, or (3) scavenger guild - species that bite an already opened test. Predator's total length $( \pm 2 \mathrm{~cm})$ and prey ingestion times $( \pm 1 \mathrm{~s})$ were also recorded.

Data analyses included calculations of percentage of observations (\%) of each fish consumer, mean body sizes and ingestion times using SPSS 15.0. Estimations of each consumer's guild diversity were performed using Simpson's index. Main predators' sizes and ingestion times were compared between urchin size classes using 1-way permutational ANOVAs with Eu- 


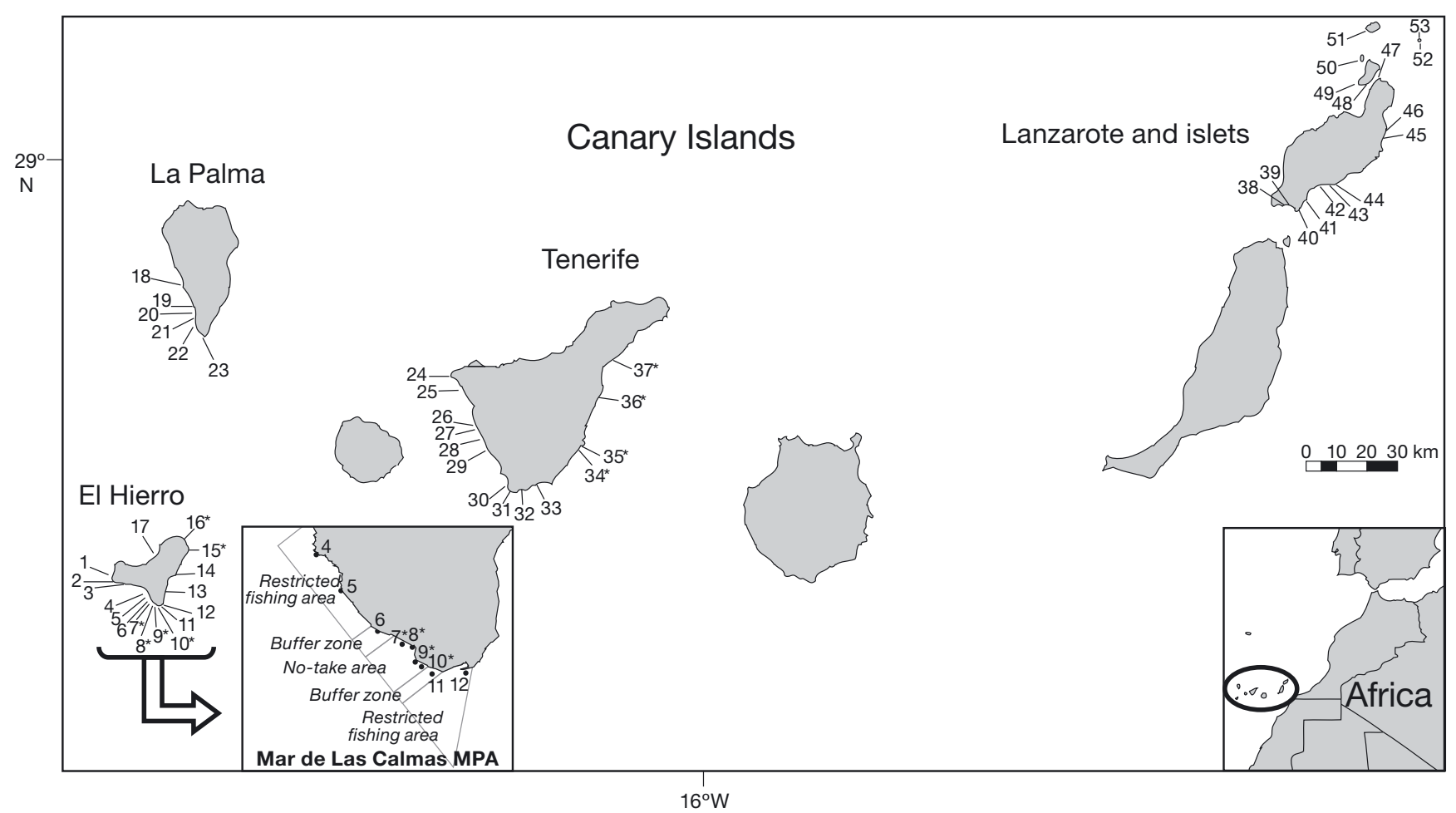

Fig. 1. Canary Islands and the 53 study sites, including zones within La Restinga-Mar de Las Calmas marine protected area (MPA). Asterisks show sites where predation observation experiments were conducted

clidean distances of raw data and 4999 permutations of the appropriate exchangeable units (Anderson 2004). When necessary, pairwise a posteriori comparisons were executed using permutations (Anderson 2004). Whenever there were not enough possible permutations to obtain a reasonable test, corrected p-values were obtained through Monte Carlo random draws from the asymptotic permutation distribution (Anderson \& Robinson 2003). Diversity indices and permutational ANOVAs were calculated with PRIMER6 \& PERMANOVA+ software.

Gut content analyses. Fish species, previously considered as potential predators of Diadema aff. antillarum (Tuya et al. 2004, Clemente et al. 2007 and references therein), were collected in coastal areas around the Canary Islands using both angling and spearing for Balistes capriscus, Canthidermis sufflamen, Bodianus scrofa, Diplodus cervinus, Diplodus sargus and Pagrus auriga, and by direct collection using hand nets for Thalassoma pavo, Canthigaster capistrata and Sphoeroides marmoratus. Fish were measured (total length, $\pm 0.1 \mathrm{~cm})$ and weighed $( \pm 0.01 \mathrm{~g})$, and their stomachs were removed. The rate of feeding activity (AC) or the percentage of stomachs with food was measured. Material was preserved in $70 \%$ alcohol, later analysed under a stereomicroscope, and echinoid remains were identified to species level (Hernández et al. 2005). Several coefficients were used to determine the importance of echinoids in the diet: (1) the occurrence index $(F)$ or percentage of non-empty stomachs that contained a prey and (2) the weight percentage of prey $(W)$ or ratio of prey weight to total weight of gut contents. Furthermore, to avoid overemphasizing occasional large prey types, (3) the ranking index $(K)$ was computed by multiplying the occurrence index by the weight of the prey (Sala \& Ballesteros 1997).

Predatory fish, indicator species of local fisheries resources and sea urchin abundance. Surveys of fish predators of Diadema aff. antillarum (defined through our previous observational and diet experiments) were conducted using an in situ stationary visual-census method. Following the point-count method, the observer took up position in the centre of a $100 \mathrm{~m}^{2}$ circle and recorded the number and size $( \pm 1 \mathrm{~cm})$ of each predator species that entered the study area during 5 min (Bortone et al. 1989). Six replicates were made at 53 sites among 4 Canarian Islands (El Hierro, La Palma, Tenerife and Lanzarote-islets) (Fig. 1), where distinct levels of fishing pressure are recorded according to Bas et al. (1995). As in previous studies evaluating the fish predators of urchins (Guidetti 2006), juvenile stages were excluded from the assessments as their numerical contri- 
bution may strongly influence density estimates without having a predatory effect (Clemente 2007, Clemente et al. 2009). Only large Canthigaster capistrata (>8 cm), Diplodus sargus $(>30 \mathrm{~cm})$, Sparisoma cretense $(>30 \mathrm{~cm})$ and Thalassoma pavo $(>12 \mathrm{~cm})$, and mediumto large-sized Diplodus cervinus $(>30 \mathrm{~cm})$ and Stephanolepis hispidus $(>12 \mathrm{~cm}$ ) were considered in the analysis as smaller individuals are unable to prey on $D$. aff. antillarum effectively (Clemente 2007, Clemente et al. 2009).

The scarid Sparisoma cretense is a highly prized fishing resource in both local recreational and commercial fisheries across the Macaronesian region and especially at the Canary Islands (Bortone et al. 1991, Bas et al. 1995). Therefore, this species abundance constitutes an indicator of fishery stock status and ecosystem service, defined as the availability of locally important fishing resources. S. cretense densities were surveyed along with densities of predatory fish of Diadema aff. antillarum. All sizes of the scarid were recorded in order to get an estimate of the whole population and the status of the nursery stock.

At each study site densities of Diadema aff. antillarum were estimated using the belt transect method. Eight $10 \times 2 \mathrm{~m}$ transects were run parallel to the coastline at 5-20 $\mathrm{m}$ depth, and all individuals sighted on the substrate were counted (Hernández et al. 2008b).

A comparison of predatory fish assemblages was made between studied islands and sites using a distance-based permutational multivariate analysis of variance (PERMANOVA) (Anderson 2004) with BrayCurtis similarities calculated among square-root-transformed density data. Relative dissimilarities among predatory fish were visualized using a principal coordinate analysis (PCO). A permutational ANOVA of total predatory density was performed with Euclidean distances of raw data. We used 2-way designs with 4999 permutations in which the factor 'Island' was fixed (4 levels) and the factor 'Site' was nested within Island (random, 53 levels). When appropriate, pairwise comparisons were executed (Anderson 2004).

Relationships between the total density of fish predators, fish species richness and Diadema aff. antillarum density were assessed by regression analyses in SPSS-15.0. We explored the relationships between urchin abundance and the density of fish that preyed on adult urchins and between urchin density and the abundance of fish preying on juveniles. The effect of urchin density on population density and nursery stock (density of juveniles: $<20 \mathrm{~cm}$ ) of the fishing resource Sparisoma cretense was also assessed. Finally, the relationships between predatory fish richness, sea urchin density and the level of fishing pressure at each island recorded as the number of fishing boats (data obtained from Bas et al. 1995, previously used by Tuya et al. 2006) were analysed.

\section{RESULTS}

\section{Predation observations}

A total of 102 predation events was counted during the experiments, and 12 fish species were observed to consume Diadema aff. antillarum: 2 balistids (Balistes capriscus, Canthidermis sufflamen), 2 labrids (Bodianus scrofa, Thalassoma pavo), 1 monacanthid (Stephanolepis hispidus), 1 pomacentrid (Abudefduf luridus), 1 scarid (Sparisoma cretense), 3 sparids (Diplodus cervinus, D. sargus, D. vulgaris) and 2 tetraodontids (Canthigaster capistrata, Sphoeroides marmoratus) (Fig. 2).

At El Hierro MPA and FA (70 observations), Balistes capriscus was the prevalent predator, followed closely by Canthidermis sufflamen and Bodianus scrofa (Fig. 2A). Urchins of 1-2 cm were mainly preyed on by $B$. scrofa and less frequently by B. capriscus (Fig. 3A). Sparisoma cretense occasionally preyed (Fig. 2A) on these smallest sizes, while C. sufflamen seemed to avoid small-sized urchins (Fig. 3A). B. scrofa was the most important predator of $2-3 \mathrm{~cm}$ individuals; $B$. capriscus was the prevalent predator of $3-4 \mathrm{~cm}$ urchins; and C. sufflamen was the prominent predator of $4-5 \mathrm{~cm}$ individuals (Fig. 3A). On allocation of consumers into other categories, we found 6 species in the attempted predator guild, including all predators except for C. sufflamen, with Thalassoma pavo totalling most unsuccessful attacks (Fig. 2B). Ten species of scavengers were observed feeding on carcasses previously opened by other predators, and T. pavo was the prevalent scavenger (Fig. 2C).

At the Tenerife HFA (32 observations) all predation events targeted juvenile urchins $<2 \mathrm{~cm}$. Diplodus sargus was the prevalent predator, followed by Thalassoma pavo, Canthigaster capistrata, Sparisoma cretense and Stephanolepis hispidus (Fig. 2A). Urchins of $<1$ and 1-2 cm were mainly preyed upon by D. sargus (Fig. 3A), and the other above-mentioned species only preyed upon the smallest individuals. The attempted predator guild comprised 7 species, including all of the predators, of which $C$. capistrata made the highest number of unsuccessful attacks (Fig. 2B). Six species of scavengers, most notably $T$. pavo, fed on juvenile urchins previously opened by other fish predators (Fig. 2C).

The range of sizes of consumed sea urchins differed between the 2 islands studied (Fig. 3). These areas also differed in terms of the species that made up each consumer category, especially within the predator guild for which there was only 1 species in common (Fig. 2). Although species richness was higher in predator and attempted predator guilds at the Tenerife HFA, diversity was slightly lower due to the predominance of Diplo- 


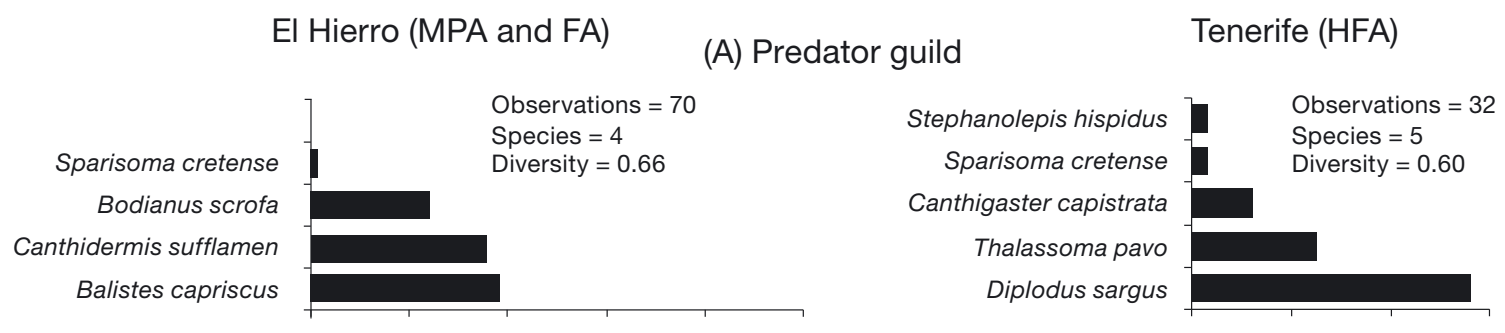

(B) Attempted predator group

\begin{tabular}{|c|c|c|c|}
\hline Bodianus scrofa & $\begin{array}{l}\text { Observations }=35 \\
\text { Species }=6 \\
\text { Diversity }=0.75\end{array}$ & $\begin{array}{r}\text { Sphoeroides marmoratus } \\
\text { Sparisoma cretense }\end{array}$ & $\begin{array}{l}\text { Observations }=33 \\
\text { Species }=7 \\
\text { Diversity }=0.72\end{array}$ \\
\hline Abudefduf luridus & & Stephanolepis hispidus & \\
\hline Balistes capriscus & & Abudefduf luridus & \\
\hline Sparisoma cretense & & Diplodus sargus & \\
\hline Canthigaster capistrata & & Thalassoma pavo & \\
\hline Thalassoma pavo & & Canthigaster capistrata & \\
\hline
\end{tabular}

(C) Scavenger guild

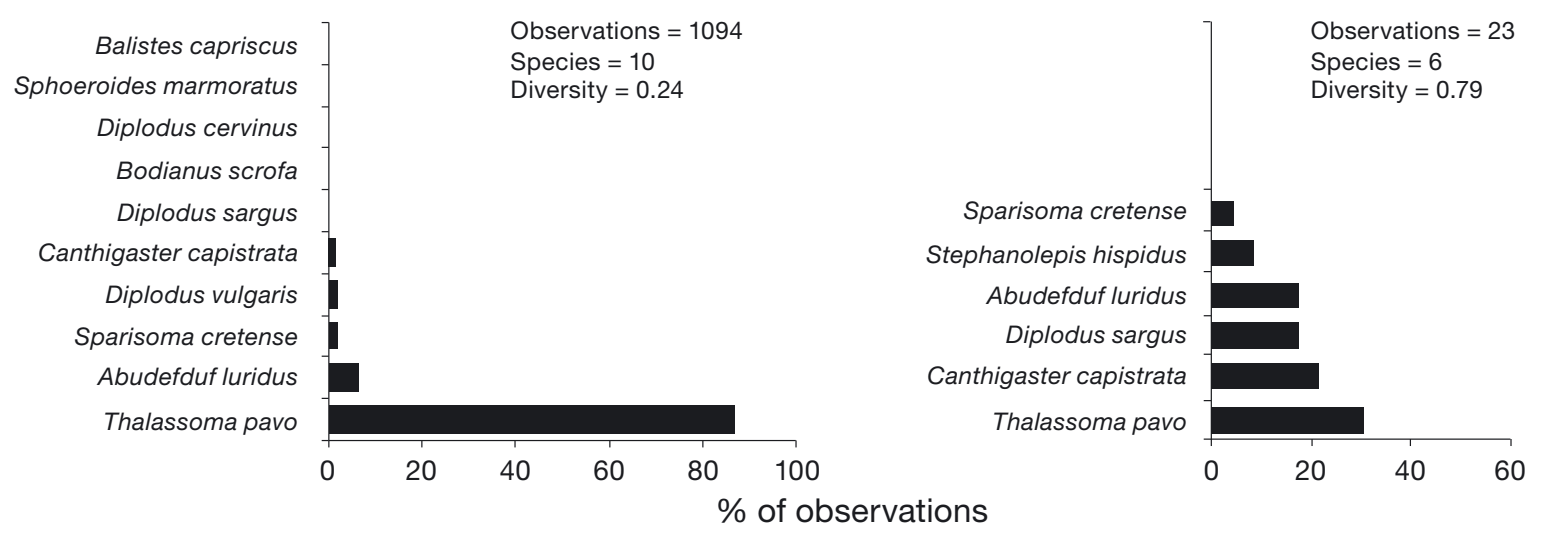

Fig. 2. Percentage of observations made up by fish species from each category of consumers of Diadema aff. antillarum: (A) predators, (B) attempted predators and (C) scavengers. Data shown for El Hierro are from both La Restinga-Mar de Las Calmas marine protected area (MPA) and a nearby fished area (FA). Data for Tenerife are from the highly fished area (HFA). Total number of observations, species richness and Simpson's diversity index are presented

dus sargus and Canthigaster capistrata, respectively (Fig. 2). Richness among scavengers was highest at El Hierro MPA/FA, but guild diversity was lowest due to the high prevalence of Thalassoma pavo (Fig. 2C).

The size of Canthidermis sufflamen preying on Diadema aff. antillarum did not increase with increasing urchin size $(F=10.12 ; \mathrm{p}=0.08)$, although it did increase in the case of Balistes capriscus $(F=4.71 ; \mathrm{p}<$ 0.05 ; Fig. 3B). B. capriscus preying on $1-2 \mathrm{~cm}$ urchins were smaller than fish preying on progressively larger urchins $(t=2.81, \mathrm{p}<0.05 ; t=2.93, \mathrm{p}<0.05 ; t=6.13, \mathrm{p}<$ 0.01, respectively; Fig. 3B). Sizes of Bodianus scrofa differed with prey size $(F=3.59$; $\mathrm{p}<0.05)$; individuals preying on $3-4$ and $4-5 \mathrm{~cm}$ urchins $(t=0.55, \mathrm{p}=0.60)$ were significantly larger $(t=2.39, \mathrm{p}<0.05 ; t=3.04, \mathrm{p}<$ 0.05 , respectively) than those consuming 1 to 2 and $2-3 \mathrm{~cm}$ urchins $(t=0.27 ; \mathrm{p}=0.89$; Fig. 3B). Sizes of
Diplodus sargus did not vary with prey sizes $(F=0.38$; $\mathrm{p}=0.55$; Fig. 3B).

Ingestion times of Balistes capriscus varied with prey size $(F=52.39 ; \mathrm{p}<0.01)$; slower times were required to consume $1-2$ and $2-3 \mathrm{~cm}$ urchins $(t=0.58 ; \mathrm{p}=0.66)$ compared to $3-4 \mathrm{~cm}(t=7.75, \mathrm{p}<0.05 ; t=7.63, \mathrm{p}<0.01)$ and to $4-5 \mathrm{~cm}$ individuals $(t=8.66, \mathrm{p}<0.05 ; t=5.86$, $\mathrm{p}<0.05$; Fig. 3C). The time required for Canthidermis sufflamen to consume a whole urchin also varied significantly between urchin sizes $(F=11.33$; $\mathrm{p}<0.01)$; ingestion of $2-3 \mathrm{~cm}$ individuals was faster than that of $3-4 \mathrm{~cm}$ urchins $(t=3.71, \mathrm{p}<0.05 ; t=3.81, \mathrm{p}<0.01)$ and, in turn, of $4-5 \mathrm{~cm}$ urchins $(t=2.92 ; \mathrm{p}<0.05$; Fig. 3C). The ingestion time for Bodianus scrofa increased with urchin size $(F=107.80 ; \mathrm{p}<0.001)$ from $1-2$ to $2-3 \mathrm{~cm}(t=4.18 ; \mathrm{p}<0.01)$ and larger urchins $(t=$ $31.12, \mathrm{p}<0.001 ; t=11.15 ; \mathrm{p}<0.01$, respectively) of $3-4$ 


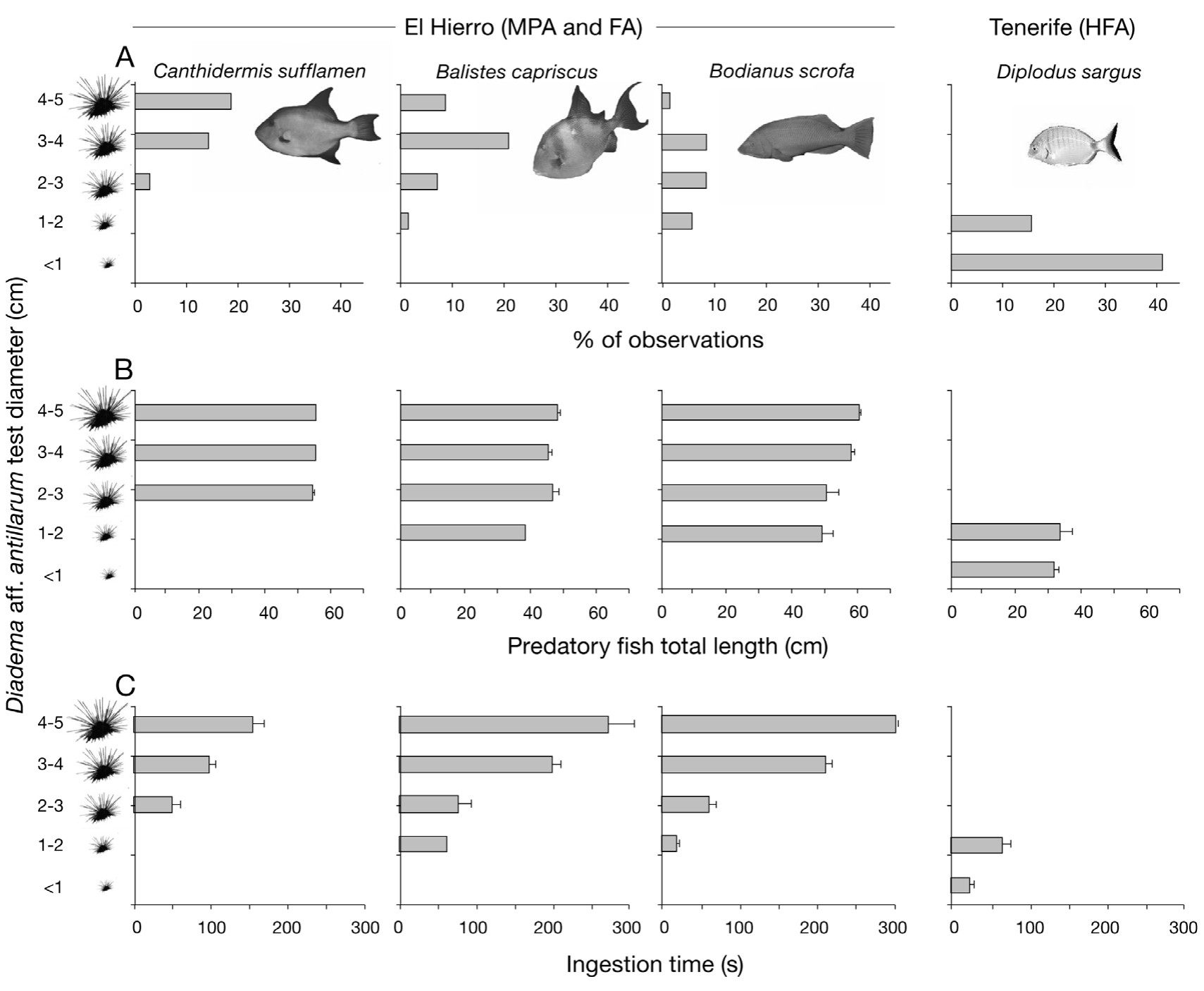

Fig. 3. Canthidermis sufflamen, Balistes capriscus, Bodianus scrofa and Diplodus sargus (from left to right). Consumption performance variables: (A) percentage of observations of predation, (B) total body length (mean \pm SE) and (C) ingestion time (mean \pm SE) displayed for each size class of Diadema aff. antillarum in La Restinga-Mar de Las Calmas marine protected area (MPA) and a nearby fished area (FA), and in Tenerife's highly fished area (HFA)

and $4-5 \mathrm{~cm}(t=2.55 ; \mathrm{p}=0.09$; Fig. 3C). Diplodus sargus ingestion time increased with increasing urchin size from $<1$ to $1-2 \mathrm{~cm}(F=14.01 ; \mathrm{p}<0.01$; Fig. 3C).

\section{Gut content analyses of fish species}

Echinoids were a fairly frequent and abundant component in the diet of Balistes capriscus. Out of the echinoids, Diadema aff. antillarum was the most frequent prey despite low scores by percentage by weight and ranking index (Table 1). Sea urchins were less frequent in the Canthidermis sufflamen diet, but represented comparatively more biomass due to $D$. aff. antillarum (Table 1).
When analysing Bodianus scrofa, echinoids were frequently consumed and represented a substantial percentage by weight, especially Diadema aff. antillarum (Table 1). The diet of the Thalassoma pavo studied showed echinoids as occasional elements, with low biomass and ranking index. $D$. aff. antillarum was the least frequently consumed sea urchin (Table 1).

Echinoids were often registered in the gut contents of Diplodus cervinus, making up intermediate percentages by weight and ranking index. Diadema aff. antillarum, although relatively frequent, was consumed to a lesser extent than other echinoids (Table 1). In D. sargus echinoids were found to be an important food item with a high ranking index, but $D$. aff. antillarum specifically was poorly consumed (Table 1). Echinoids resulted as secondary items in the diet of Pagrus auriga, 
Table 1. Diet analyses of 9 fish species, showing the occurrence index $(F)$, percentage by weight $(W)$ and ranking index $(K)$ of echinoid preys and specifically of Diadema aff. antillarum. N: number of individuals; AC: activity index; S: size range $(\mathrm{cm}) ; \mathrm{WW}$ : wet weight range of examined fish $(\mathrm{g})_{i}<$ : values $<0.01$

\begin{tabular}{|c|c|c|c|c|}
\hline Fish species & Prey items & $F$ & $W$ & $K$ \\
\hline \multicolumn{5}{|l|}{ Balistes capriscus } \\
\hline (N: 12; AC: $83.33 ;$ S: 29-52; & All echinoids & 40.00 & 30.25 & 6.05 \\
\hline \multirow[t]{2}{*}{ WW: 441-1400) } & D. aff. antillarum & 30.00 & 1.06 & 0.32 \\
\hline & Other echinoids & 10.00 & 29.19 & 2.92 \\
\hline \multicolumn{5}{|l|}{ Canthidermis sufflamen } \\
\hline (N: 29; AC: 89.66; S: 34-62; & All echinoids & 7.69 & 11.65 & 0.90 \\
\hline \multirow[t]{2}{*}{ WW: 983-3700) } & D. aff. antillarum & 7.69 & 6.09 & 0.47 \\
\hline & Other echinoids & 3.85 & 5.56 & 0.21 \\
\hline \multicolumn{5}{|l|}{ Bodianus scrofa } \\
\hline \multirow{3}{*}{$\begin{array}{l}(\mathrm{N}: 18 ; \mathrm{AC}: 88.89 ; \mathrm{S}: 19.70-53.00 \\
\text { WW: } 104-3500)\end{array}$} & All echinoids & 68.75 & 25.70 & 17.67 \\
\hline & D. aff. antillarum & 37.50 & 14.10 & 5.29 \\
\hline & Other echinoids & 50.00 & 11.60 & 5.80 \\
\hline \multicolumn{5}{|l|}{ Thalassoma pavo } \\
\hline$(\mathrm{N}: 46 ; \mathrm{AC}: 71.74 ; \mathrm{S}: 8.00-19.00 ;$ & All echinoids & 45.45 & 2.66 & 1.21 \\
\hline \multirow{2}{*}{ WW: $7-79)$} & D. aff. antillarum & 3.03 & $<$ & $<$ \\
\hline & Other echinoids & 41.18 & 2.66 & 1.09 \\
\hline \multicolumn{5}{|l|}{ Diplodus cervinus } \\
\hline (N: 11; AC: 90.91; S: 18-43; & All echinoids & 80.00 & 3.92 & 3.14 \\
\hline \multirow[t]{2}{*}{ WW: 213-1750) } & D. aff. antillarum & 40.00 & 0.39 & 0.15 \\
\hline & Other echinoids & 70.00 & 3.53 & 2.47 \\
\hline \multicolumn{5}{|l|}{ Diplodus sargus } \\
\hline \multirow{3}{*}{$\begin{array}{l}\text { (N: } 32 ; \text { AC: } 87.50 ; \text { S: } 18-45 ; \\
\text { WW: } 156-101)\end{array}$} & All echinoids & 60.71 & 30.52 & 18.53 \\
\hline & D. aff. antillarum & 7.14 & 0.12 & 0.01 \\
\hline & Other echinoids & 57.14 & 30.40 & 17.37 \\
\hline \multirow{4}{*}{$\begin{array}{l}\text { Pagrus auriga } \\
\text { (N: } 20 ; \text { AC: } 95.00 ; \text { S: } 25-70 ; \\
\text { WW: }- \text { ) }\end{array}$} & & & & \\
\hline & All echinoids & 36.84 & 2.39 & 0.88 \\
\hline & D. aff. antillarum & 5.26 & $<$ & $<$ \\
\hline & Other echinoids & 31.58 & 2.39 & 0.75 \\
\hline \multirow{3}{*}{$\begin{array}{l}\text { Canthigasther capistrata } \\
\text { (N: 22; AC: 100.00; S: 5.50-9.50; } \\
\text { WW: 5-27) }\end{array}$} & & & & \\
\hline & All echinoids & $\begin{array}{l}95.45 \\
40.91\end{array}$ & $\begin{array}{l}14.49 \\
12.96\end{array}$ & $\begin{array}{r}13.82 \\
5.30\end{array}$ \\
\hline & $\begin{array}{l}\text { D. aff. antillarum } \\
\text { Other echinoids }\end{array}$ & $\begin{array}{l}40.91 \\
54.54\end{array}$ & 1.52 & 0.83 \\
\hline \multirow{4}{*}{$\begin{array}{l}\text { Sphoeroides marmoratus } \\
\text { (N: } 11 ; \text { AC: } 90.91 \text {; S: } 7.00-15.00 ; \\
\text { WW: } 7-41 \text { ) }\end{array}$} & & & & \\
\hline & All echinoids & 70.00 & 4.20 & 2.94 \\
\hline & D. aff. antillarum & 20.00 & 0.22 & 0.04 \\
\hline & Other echinoids & 60.00 & 3.98 & 2.39 \\
\hline
\end{tabular}

with $D$. aff. antillarum accounting for a very low proportion (Table 1).

In the diet of Canthigaster capistrata echinoids appeared frequently, representing an important proportion of consumed biomass, especially Diadema aff. antillarum (Table 1). Conversely, echinoids did not represent large proportions of biomass, nor did they score highly in the ranking index when examining the diet of Sphoeroides marmoratus (Table 1).

\section{Predatory fish, indicator species of local fisheries resources and sea urchin abundance}

There were significant differences in the assemblage of Diadema aff. antillarum predatory fish between studied islands and sites within islands (Table 2A). Differences between El Hierro and La Palma, although still significant, were smaller than between other islands (Table 2A, Fig. 4). The spatial variation found in the fish community was mainly due to the most abundant and frequent species Thalassoma pavo and Canthigaster capistrata (Table 3), and to a lesser extent, to Sparisoma cretense, Diplodus cervinus and Balistes capriscus (Fig. 4). S. cretense, D. cervinus and $B$. capriscus appeared more frequently and in higher abundances in El Hierro and La Palma (Table 3). Less

Table 2. (A) PERMANOVA on predatory fish assemblage of the sea urchin Diadema aff. antillarum, based on square-root fishabundance data and assessing differences between studied islands and sites of the Canary Islands. (B) Permutational ANOVA of original raw data on predatory fish total density to assess differences between studied islands and sites. Estimates for pairwise comparisons of significant effects of the factor 'Island' in each analysis are shown. NS: not significant; ${ }^{*} \mathrm{p}<0.05 ;{ }^{* *} \mathrm{p}<0.01$

\begin{tabular}{|c|c|c|c|c|c|c|c|c|c|c|}
\hline \multirow[b]{2}{*}{ Source of variation } & \multicolumn{5}{|c|}{ (A) PERMANOVA on predatory fish density } & \multicolumn{5}{|c|}{ (B) ANOVA on total predatory fish density } \\
\hline & df & SS & MS & $F$ & $\mathrm{p}($ perm $)$ & $\mathrm{df}$ & SS & MS & $F$ & $\mathrm{p}($ perm $)$ \\
\hline Island & 3 & 59451.00 & 19817.00 & 7.80 & *** & 3 & 24479.00 & 8159.60 & 12.96 & ** \\
\hline Site (Island) & 49 & $1.25 \mathrm{E} 5$ & 2550.50 & 2.43 & ** & 49 & 30755.00 & 627.64 & 0.68 & NS \\
\hline Residual & 259 & $2.71 \mathrm{E} 5$ & 1048.40 & & & 259 & $2.40 \mathrm{E} 5$ & 926.81 & & \\
\hline Total & 311 & $4.59 \mathrm{E} 5$ & & & & 311 & 2.96 E5 & & & \\
\hline \multicolumn{4}{|l|}{ Pairwise analyses } & $t$ & $\mathrm{p}($ perm $)$ & & & & $t$ & $\mathrm{p}($ perm $)$ \\
\hline \multicolumn{4}{|l|}{ El Hierro vs. La Palma } & 1.67 & * & & & & 0.20 & NS \\
\hline \multicolumn{4}{|l|}{ El Hierro vs. Tenerife } & 2.79 & ** & & & & 3.36 & $* *$ \\
\hline \multicolumn{4}{|c|}{ El Hierro vs. Lanzarote-islets } & 2.79 & ** & & & & 5.32 & ${ }^{* *}$ \\
\hline \multicolumn{4}{|c|}{ La Palma vs. Tenerife } & 4.10 & ** & & & & 2.87 & $*$ \\
\hline \multicolumn{4}{|c|}{ La Palma vs. Lanzarote-islets } & 2.57 & *** & & & & 5.10 & ** \\
\hline \multicolumn{4}{|c|}{ Tenerife vs. Lanzarote-islets } & 3.24 & ** & & & & 2.56 & * \\
\hline
\end{tabular}




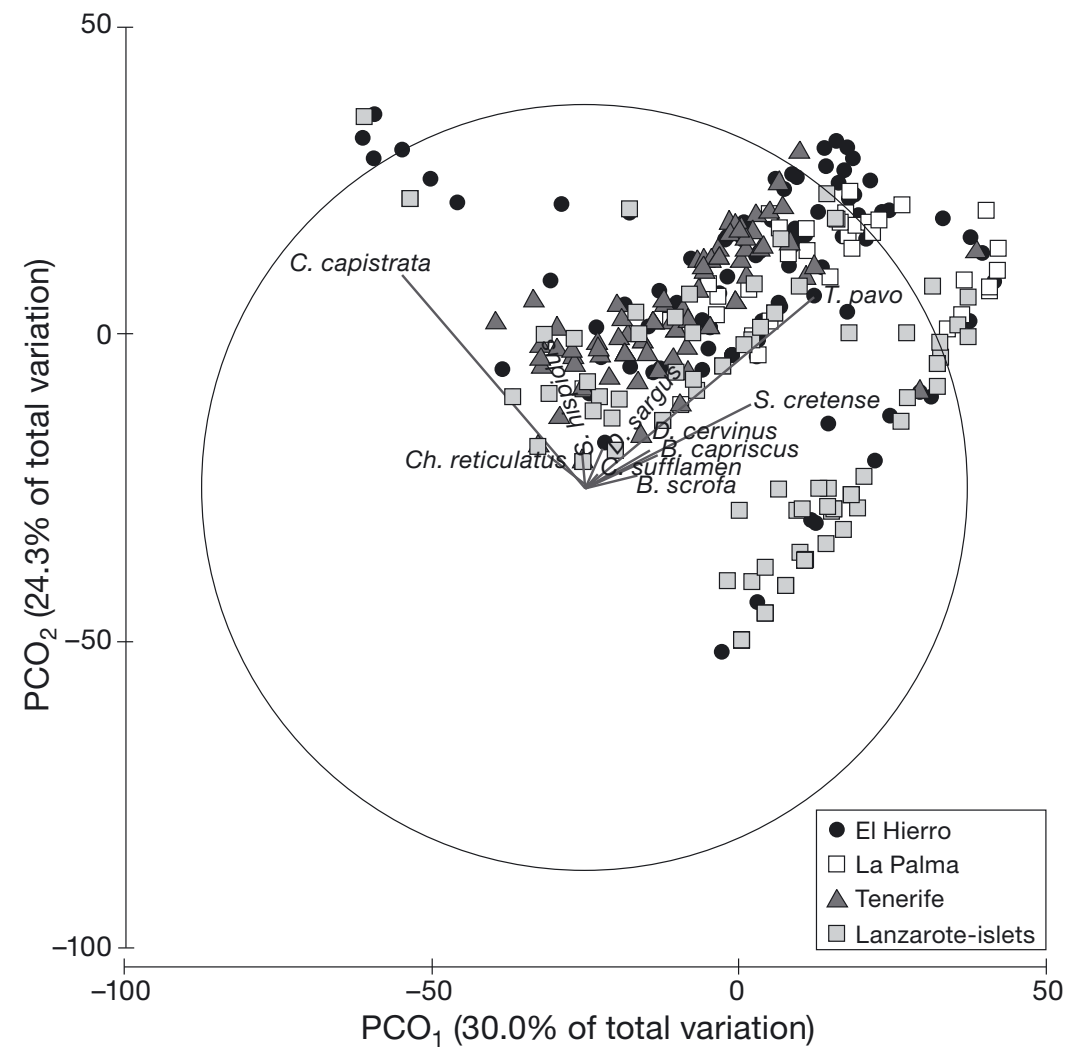

Fig. 4. Principal coordinate analysis (PCO) showing the first 2 axes $(54.3 \%$ of variability), based on Bray-Curtis dissimilarities of square-root-transformed data of Diadema aff. antillarum predatory fish abundances (Balistes capriscus, Canthidermis sufflamen, Chilomycterus reticulatus, Bodianus scrofa, Thalassoma pavo, Diplodus cervinus, D. sargus, Canthigaster capistrata, Stephanolepis hispidus and Sparisoma cretense) at the islands in the archipelago studied

frequent species such as Canthidermis sufflamen, Bodianus scrofa and Chilomycterus reticulatus were also more abundant at these western islands (Table 3). The PCO showed greater dispersion of data corresponding to El Hierro, where higher variability in abundance and composition of predatory fish community occurred (Fig. 4). Data from Tenerife and most surveys of Lanzarote-islets were less dispersed and varied mainly according to the abundance of T. pavo and C. capistra$t a$, while those from La Palma comprised a group mainly dominated by $T$. pavo, $S$. cretense, D. cervinus and B. capriscus (Fig. 4).

When considering total density of urchin predatory fish, a significant effect of 'Island' was found, with higher values at El Hierro and La Palma than at Tenerife and Lanzarote-islets (Tables 2B \& 3). Significant negative and exponential relationships were detected between total abundance of predatory fish and urchin density (Fig. 5A), and between predatory fish richness and urchin density (Fig. 5B). Variability of urchin density tended to decrease at fish densities $>25$ ind. $100 \mathrm{~m}^{-2}$ and at richness values of 7 predatory species
(Fig. 5A,B). Urchin abundance varied exponentially and inversely with total density of juvenile urchin fish predators (Diplodus cervinus, D. sargus, Thalassoma pavo, Canthigaster capistrata, Sparisoma cretense, Stephanolepis hispidus), but a much more adjusted negative logarithmic relationship was obtained between predators of adults (Balistes capriscus, Canthidermis sufflamen, Bodianus scrofa, Chilomycterus reticulatus) and urchin density (Fig. 5D). At low fish abundances, urchin density showed a wide data dispersion, decreasing variability sharply at a threshold density of 0.5 predators of adult urchins $100 \mathrm{~m}^{-2}$, a density that kept urchins below 2 ind. $\mathrm{m}^{-2}$ (Fig. 5D).

A significant and negative logarithmic relationship was obtained between sea urchin abundances and densities of the fishing resource Sparisoma cretense (Fig. 5E). Abundances of juvenile $S$. cretense varied logarithmically and inversely with urchin densities (Fig. 5F). Moreover, significant log-linear relationships were detected between predatory fish species richness and the number of fishing boats at each island $\left(y=-0.75 \ln (x)+8.03 ; \mathrm{R}^{2}=0.94 ; \mathrm{p}<\right.$ $0.05)$, and between urchin density and fishing effort $\left(y=2.06 \ln (x)-5.07 ; \mathrm{R}^{2}=\right.$ $0.98 ; \mathrm{p}<0.01)$. The highest urchin density and lowest fish richness were obtained at Tenerife HFA (265 boats). At the least FA of El Hierro (15 boats) the trend was the opposite; urchin densities were lowest and predatory richness highest.

\section{DISCUSSION}

The present study has revealed that several fish species can consume the sea urchin Diadema aff. antillarum in eastern Atlantic sublittoral rocky habitats, though only a few are able to break open their tests. We have shown that by controlling sea urchin populations, and thus the amount of macroalgal cover left intact (Hernández et al. 2008a), predatory fish indirectly determine the ecosystem's services or capacity to provide locally important fishing resources.

Day-time predators of Diadema aff. antillarum included a guild of 8 fish species, dominated by the balistids Balistes capriscus and Canthidermis sufflamen and the labrid Bodianus scrofa and by the predators of juvenile urchins such as the sparid Diplodus sargus 
Table 3. Densities (means $\pm \mathrm{SE}$ ) of identified predatory fish species of the sea urchin Diadema aff. antillarum and percentage presence at survey sites around the Canarian Archipelago

\begin{tabular}{|c|c|c|}
\hline Fish species & $\begin{array}{c}\text { Density } \\
\text { (ind. } 100 \mathrm{~m}^{-2} ; \\
\text { mean } \pm \mathrm{SE} \text { ) }\end{array}$ & $\begin{array}{l}\text { Percent } \\
\text { presence }\end{array}$ \\
\hline \multicolumn{3}{|l|}{ El Hierro } \\
\hline Balistes capriscus & $0.06 \pm 0.02$ & 35.29 \\
\hline Bodianus scrofa & $0.14 \pm 0.04$ & 35.29 \\
\hline Canthidermis sufflamen & $0.37 \pm 0.30$ & 29.41 \\
\hline Canthigaster capistrata & $3.21 \pm 0.45$ & 94.19 \\
\hline Chilomycterus reticulatus & $0.02 \pm 0.01$ & 11.76 \\
\hline Diplodus cervinus & $0.53 \pm 0.09$ & 82.35 \\
\hline Diplodus sargus & $0.58 \pm 0.27$ & 47.06 \\
\hline Sparisoma cretense & $0.55 \pm 0.10$ & 76.47 \\
\hline Stephanolepis hispidus & $0.04 \pm 0.02$ & 23.53 \\
\hline Thalassoma pavo & $25.43 \pm 4.60$ & 100.00 \\
\hline Total & $30.92 \pm 4.65$ & \\
\hline \multicolumn{3}{|l|}{ La Palma } \\
\hline Balistes capriscus & $0.39 \pm 0.14$ & 50.00 \\
\hline Bodianus scrofa & $0.14 \pm 0.07$ & 50.00 \\
\hline Canthidermis sufflamen & $0.00 \pm 0.00$ & 0.00 \\
\hline Canthigaster capistrata & $1.44 \pm 0.21$ & 100.00 \\
\hline Chilomycterus reticulatus & $0.00 \pm 0.00$ & 0.00 \\
\hline Diplodus cervinus & $0.94 \pm 0.31$ & 50.00 \\
\hline Diplodus sargus & $0.17 \pm 0.07$ & 50.00 \\
\hline Sparisoma cretense & $1.78 \pm 0.33$ & 100.00 \\
\hline Stephanolepis hispidus & $0.17 \pm 0.06$ & 50.00 \\
\hline Thalassoma pavo & $24.64 \pm 4.47$ & 100.00 \\
\hline Total & $29.67 \pm 4.48$ & \\
\hline \multicolumn{3}{|l|}{ Tenerife } \\
\hline Balistes capriscus & $0.00 \pm 0.00$ & 0.00 \\
\hline Bodianus scrofa & $0.00 \pm 0.00$ & 0.00 \\
\hline Canthidermis sufflamen & $0.00 \pm 0.00$ & 0.00 \\
\hline Canthigaster capistrata & $4.91 \pm 0.40$ & 100.00 \\
\hline Chilomycterus reticulatus & $0.00 \pm 0.00$ & 0.00 \\
\hline Diplodus cervinus & $0.01 \pm 0.01$ & 7.14 \\
\hline Diplodus sargus & $1.36 \pm 0.59$ & 50.00 \\
\hline Sparisoma cretense & $0.05 \pm 0.02$ & 21.43 \\
\hline Stephanolepis hispidus & $0.04 \pm 0.02$ & 21.43 \\
\hline Thalassoma pavo & $10.51 \pm 0.98$ & 100.00 \\
\hline Total & $16.87 \pm 1.41$ & \\
\hline \multicolumn{3}{|l|}{ Lanzarote-islets } \\
\hline Balistes capriscus & $0.01 \pm 0.01$ & 6.25 \\
\hline Bodianus scrofa & $0.01 \pm 0.01$ & 6.25 \\
\hline Canthidermis sufflamen & $0.00 \pm 0.00$ & 0.00 \\
\hline Canthigaster capistrata & $0.97 \pm 0.18$ & 87.50 \\
\hline Chilomycterus reticulatus & $0.00 \pm 0.00$ & 0.00 \\
\hline Diplodus cervinus & $0.50 \pm 0.19$ & 37.50 \\
\hline Diplodus sargus & $0.64 \pm 0.22$ & 50.00 \\
\hline Sparisoma cretense & $0.30 \pm 0.07$ & 56.25 \\
\hline Stephanolepis hispidus & $0.02 \pm 0.02$ & 6.25 \\
\hline Thalassoma pavo & $7.48 \pm 0.98$ & 100.00 \\
\hline Total & $9.93 \pm 1.03$ & \\
\hline
\end{tabular}

and labrid Thalassoma pavo. The relatively low richness and diversity of predators may result from the aggressive behaviour displayed by frequent predatory balistids (McClanahan 1995) and by D. sargus (Sala 1997), as it may exclude competitors. The pool of scavengers was more speciose and diverse at HFAs, while the prevalence of T. pavo in the MPA and lesser FAs reduced intraguild diversity. The lower number of scavengers in HFAs could also be related to the main predator's (D. sargus) aggressive and feeding behaviour that often involved swallowing entire sea urchins, thus leaving nothing to scavenge. The finding that fish diversity and abundance are reduced in HFAs fits in with what has been observed at other overfished areas around the world (Pauly et al. 1998, Jackson et al. 2001, Myers \& Worm 2003), with implications for preserving the function of fish consumers in degraded ecosystems.

The predator guild obtained from observations did not include all species previously considered as potential predators of Diadema aff. antillarum (Tuya et al. 2004). We may have failed to observe some night-time, rare or deep-water predators, possibly leading to bias in guild composition. Underrepresented species may have been the diodontid Chilomycterus reticulatus, a relevant predator of large sea urchins (Brito \& Falcón 1990) that appears occasionally in the western islands, and the sparid Pagrus auriga, common in deeper waters (Brito et al. 2002). In addition, the experimental procedure that involved positioning urchins outside shelter to facilitate observations may have increased their susceptibility. However, gut-content analyses determined that urchins are naturally present in the diet of the fish we observed and added 3 more species to the list of urchin consumers ( $P$. auriga, Diplodus cervinus and Sphoeroides marmoratus).

Some variation was observed in the prevalence of predatory fish among studied areas. Whereas predator guild in less exploited fishing areas included species capable of predation on all urchin sizes, at HFAs only species that consume juveniles were observed. This is closely related to the differences found in fish assemblage distribution throughout the Canary Islands and to previous results indicating that predation pressure on Diadema aff. antillarum is very low at HFAs (Clemente et al. 2007). Species such as Balistes capriscus and Bodianus scrofa are much more abundant in the western islands, while at HFAs of the central-eastern islands, they are rare. Canthidermis sufflamen is an occasional inhabitant of rocky bottoms and open waters of the central-western islands (Brito et al. 2002), yet specifically at El Hierro it becomes common. It was at barren grounds within HFAs where Diplodus sargus and Thalassoma pavo, widespread throughout the archipelago, were found to be the most frequent predators of urchins $<2 \mathrm{~cm}$. Switches in species composition of the $D$. aff. antillarum predator guild occur throughout the archipelago, probably due to the different densities each species achieves locally and the incidence of fishing. Our results show that increased fishing effort is associated with lower numbers of 

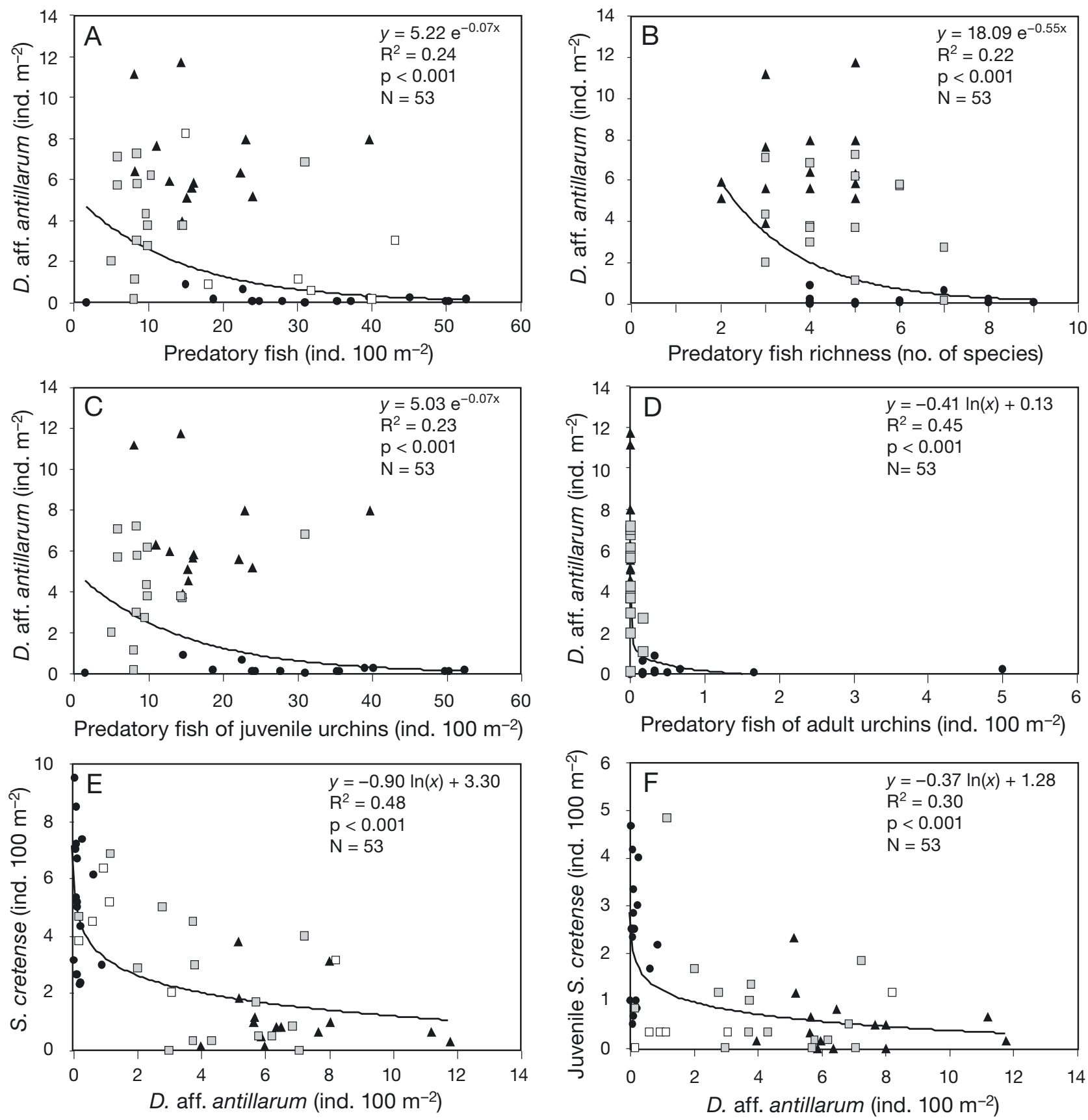

Fig. 5. Diadema aff. antillarum. Exponential relationships between density of the sea urchin D. aff. antillarum and (A) total abundance of urchin predatory fish, (B) species richness of predatory fish and (C) abundance of predators of juvenile urchins. Log-linear relationships between $D$. aff. antillarum density and (D) abundance of predatory fish of adult urchins, (E) population density of $S p a r i-$ soma cretense (an indicator species of local fisheries resources) and (F) abundance of juvenile $S$. cretense $(<20 \mathrm{~cm}$ total length).

•: El Hierro; $\mathbf{\Delta}$ : Tenerife; 口: La Palma; $\square$ : Lanzarote-islets

predatory species and higher urchin densities, suggesting that the removal of predators may be responsible for the Canary Islands' dramatic shift from beds dominated by erect macroalgae to barrens where coralline algae prevail (Hernández et al. 2008a).

Sea urchin predation appeared to be dependent on both predator and prey sizes. Fishing results in loss of fish sizes and species capable of consuming large sea urchins. Consequently, Diadema aff. antillarum of different TDs were found to vary in their susceptibility to predation among study areas. In HFAs, urchins showed a smaller 'escape size' from fish predation (Sala 1997) $(\approx 2 \mathrm{~cm}$ TD), which favours their proliferation. However, in less exploited fishing areas large 
urchins were still vulnerable, which demonstrates the importance of fish assemblages in structuring populations of echinoids.

Knowledge of the identity of species occupying a particular trophic position and their consumption habits is crucial to predicting their impacts on the community and the consequences of any potential shift in composition and abundance. The assumption that communities consist of groups of functionally similar species and that this redundancy provides insurance against loss of ecological processes is persistent in ecological studies (Walker 1992). However, our results, as well as other studies (Bellwood et al. 2003, Worm et al. 2006), suggest that functional redundancy may be rare within a given trophic level. For most measures of predatory performance, such as frequency of predation, ingestion time and prey size selection, we found that predatory fish of Diadema aff. antillarum were not functionally similar. The 11 defined predator species had different impacts on sea urchin populations, and any variation in their relative distribution across environmental gradients therefore influences prey dynamics, prey distribution and ultimately the local ecosystem. It is precisely this level of variation that highlights the importance of biodiversity and of understanding how ecosystem function may respond to loss of species.

We have used a correlation approach to infer mechanistic links across trophic levels, not excluding the possibility that any one link might be the result of unknown factors. However, our observational experiments included the assessment of predator feeding activity by measuring different performance variables, which backed up mechanisms identified in correlations. High predator richness was associated with low prey density, but the extent of control over urchin abundance was much stronger among fish capable of predation on a wide size range of prey. This indicates that predators can have complementary effects, but also points out the potential importance of certain predatory species. Predator richness may influence herbivore populations, and indirectly algal systems, in several ways. The probability of selecting a key species increases with species richness, then species identity would be more relevant than diversity per se. But species can also have complementary effects due to facilitation (Huston 1997, Benedetti-Cecchi 2004), or, alternatively, antagonistic effects may occur (Guidetti 2007); hence, the number of species would be relevant. Although our observational experiments did not allow us to specifically differentiate between the effects of species identity and biodiversity, results suggest that the extent of change associated with predator loss will depend on the particular species in question and its ability to reduce the abundance of prey, which is not considered in generalized food web theory (Hairston et al. 1960). Our findings support the keystone predation model (Leibold 1996), which is built on the presumption that there can be functional variability between species at the same trophic level; however, further experiments to specifically test the effects of predator identity and diversity are necessary (Benedetti-Cecchi 2004). In any case, maintaining predatory fish richness appears to be critical in preserving sublittoral systems, since it results in reduced urchin density and in positive cascade effects on macroalgae. Erect macroalgal communities are important habitat-providers (Hernández et al. 2008b) and constitute a major energy source that maintains the food web at the Canary Islands. Declining predator diversity can therefore have significant consequences on the structure and function of the ecosystem, causing impacts that harm the local economy such as the depletion of Sparisoma cretense stocks, a heavily targeted herbivore.

The identification of Diadema aff. antillarum predators is extremely useful for ecosystem management off the Canary Islands, especially since a recent sea urchin population outbreak has altered benthic communities (Hernández et al. 2008a). Regardless of other factors involved, the regulation of sea urchin populations may be achieved by aiding the recovery of predatory fish. Sublittoral rocky reefs strongly impacted by fishing showed depletion or absence of key predatory fish, with important ecological consequences. Fisheries regulations should promote the recovery and conservation of functionally important predatory fishes in order to maximize predation over the whole size spectrum of the key herbivore prey Diadema aff. antillarum. The functioning and services of sublittoral rocky ecosystems can substantially be altered by the simultaneous absence of some of the identified predators such as Balistes capriscus, Canthidermis sufflamen and Bodianus scrofa. Such species should be designated 'keystone species' (Paine 1966, Piraino et al. 2002) or members of a 'keystone guild' (McClanahan 1995) and protected by future management policies.

Our findings add to a growing body of research suggesting that top-down control of key herbivores is highly correlated with human disturbance (Steneck 1998, Jackson et al. 2001, Guidetti \& Sala 2007). The long-term depletion of high trophic level fish triggers shifts in the food web that are closely tied to the output of fishing resources. In conclusion, variations in size and species composition of predators, caused by fishing or natural processes such as spatial changes within local communities, can have important consequences for food webs. In many cases, the importance of this variation is overlooked, assuming that all species occupying a similar trophic level act in a similar manner. According to a more realistic scenario of ecological 
performance variability, a loss or depletion in species diversity constitutes a real loss of functional roles and subsequent cascading effects that may constrain ecosystem processes. When establishing conservation priorities we need to appreciate the importance of both species composition and functional roles.

Acknowledgements. We are grateful to C. Sangil, K. Toledo, J. M. Falcón, D. Girard and O. Monterroso for their sampling efforts. J. Mora and H. Lopez provided specimens for diet analyses, and I. González helped with dissections. N. Aguilar and M. Johnson provided accommodation at El Hierro. E. Sala, J. Manning (from 'Science Correct') and 2 anonymous referees improved earlier versions of the manuscript. The present study was funded by the Spanish 'Ministerio de Educación y Ciencia' through postgraduate fellowships to S.C. and J.C.H.

\section{LITERATURE CITED}

Anderson MJ (2004) PERMANOVA 2factor: a FORTRAN computer program for permutational multivariate analysis of variance using permutation tests. University of Auckland, Auckland

Anderson MJ, Robinson J (2003) Generalised discriminant analysis based on distances. Aust NZ J Stat 45:301-318

Armsworth PR, Chan KMA, Daily GC, Ehrlich PR, Kremen C, Ricketts TH, Sanjayan MA (2007) Ecosystem-service science and the way forward for conservation. Conserv Biol 21:1383-1384

Bas C, Castro JJ, Hernández-García V, Lorenzo JM, Moreno T, Pajuelo JG, González-Ramos AJ (1995) La Pesca en Canarias y áreas de influencia. Ediciones del Cabildo Insular de Gran Canaria, Las Palmas

Bellwood DR, Hoey AS, Choat JH (2003) Limited functional redundancy in high diversity systems: resilience and ecosystem function on coral reefs. Ecol Lett 6:281-285

Benedetti-Cecchi L (2004) Increasing accuracy of causal inference in experimental analyses of biodiversity. Funct Ecol 18:761-768

Bortone SA, Kimmel JJ, Bundrick CM (1989) A comparison of three methods for visually assessing reef fish communities: time and area compensated. Northeast Gulf Sci 10: 85-96

Bortone SA, Van Tassell JT, Brito A, Falcón JM, Bundrick CM (1991) A visual assessment of the inshore fishes and fishery resources off E1 Hierro, Canary Islands: a baseline survey. Sci Mar 55:529-541

Brito A, Falcón JM (1990) Contribución al conocimiento de la distribución y ecología de Chilomycterus atringa (Pises, Diodontidae) en las Islas Canarias. Vieraea 19:271-275

Brito A, Pascual PJ, Falcón JM, Sancho A, González-Lorenzo G (2002) Peces de las Islas Canarias. Catálogo comentado e ilustrado. Francisco Lemus Editor, La Laguna

Clemente S (2007) Evolución de las poblaciones del erizo Diadema aff. antillarum en Canarias y valoración de la depredación como factor de control. PhD dissertation, Universidad de La Laguna, Tenerife

Clemente S, Hernández JC, Toledo K, Brito A (2007) Predation upon Diadema aff. antillarum at barrens grounds in the Canary Islands. Sci Mar 71:745-754

> Clemente S, Hernández JC, Brito A (2009) Evidence of the top-down role of predators in structuring sublittoral rockyreef communities in a Marine Protected Area and nearby areas of the Canary Islands. ICES J Mar Sci 66:64-71
De Groot RS, Wilson MA, Boumans RMJ (2002) A typology for the classification, description and valuation of ecosystem functions, goods and services. Ecol Econ 41:393-408

Guidetti P (2004) Consumers of sea urchins, Paracentrotus lividus and Arbacia lixula, in shallow Mediterranean rocky reefs. Helgol Mar Res 58:110-116

> Guidetti P (2006) Marine reserves reestablish lost predatory interactions and cause community effects in rocky reefs. Ecol Appl 16:963-976

Guidetti P (2007) Predator diversity and density affect levels of predation upon strongly interactive species in temperate rocky reefs. Oecologia 154:513-520

Guidetti P, Sala E (2007) Community-wide effects of marine reserves in the Mediterranean Sea. Mar Ecol Prog Ser 335: $43-56$

> Hairston NG, Smith FE, Slobodkin LB (1960) Community structure population control and competition. Am Nat 94: $421-425$

Hernández JC, Toledo K, Girard D, Clemente S, Cubero E, Brito A (2005) Descripción de la post-larva y primeras fases juveniles de tres equinoideos presentes en las islas Canarias: Diadema antillarum Philippi, 1845, Paracentrotus lividus (Lamarck, 1816) y Arbaciella elegans Mortensen, 1910. Vieraea 33:385-397

> Hernández JC, Clemente S, Sangil C, Brito A (2008a) The key role of the sea urchin Diadema aff. antillarum in controlling macroalgae assemblages throughout the Canary Islands (eastern subtropical Atlantic): a spatio-temporal approach. Mar Environ Res 66:259-270

> Hernández JC, Clemente S, Sangil C, Brito A (2008b) Actual status of the sea urchin Diadema aff. antillarum populations and macroalgal cover in the Marine Protected Areas comparing to a highly fished area (Canary Islands-eastern Atlantic Ocean). Aquat Conserv 18:1091-1108

Holmlund CM, Hammer M (1999) Ecosystem services generated by fish populations. Ecol Econ 29:253-268

Huston MA (1997) Hidden treatments in ecological experiments: reevaluating the ecosystem function of biodiversity. Oecologia 110:449-460

Jackson JBC, Kirby MX, Berger WH, Bjorndal KA and others (2001) Historical overfishing and the recent collapse of coastal ecosystems. Science 293:629-638

Leibold MA (1996) A graphical model of keystone predators in food webs: trophic regulation of abundance, incidence and diversity patterns in communities. Am Nat 147: $784-812$

McClanahan TR (1995) Fish predators and scavengers of the sea urchin Echinometra mathaei in Kenyan coral-reef marine parks. Environ Biol Fishes 43:187-193

McClanahan TR (2000) Coral reef use and conservation. In: McClanahan TR, Sheppard CRC, Obura DO (eds) Coral reef of the Indian Ocean. Their ecology and conservation. Oxford University Press, New York, NY, p 39-80

> McClanahan TR, Muthiga NA (1989) Patterns of predation on a sea urchin, Echinometra mathaei (de Blainville), on Kenyan coral reefs. J Exp Mar Biol Ecol 126:77-94

- Myers RA, Worm B (2003) Rapid worldwide depletion of predatory fish communities. Nature 423:280-283

> Paine RT (1966) Food web complexity and species diversity. Am Nat 100:65-75

Paine RT (1980) Food webs linkage interaction strength and community infrastructure. J Anim Ecol 49:667-685

> Pauly D, Christensen V, Dalsgaard J, Froese R, Torres FJ (1998) Fishing down marine food webs. Science 279:860-863

Piraino S, Fanelli G, Boero F (2002) Variability of species' roles in marine communities: change of paradigms for conservation priorities. Mar Biol 140:1067-1074 
Sala E (1997) Fish predators and scavengers of the sea urchin Paracentrotus lividus in protected areas of the North-West Mediterranean Sea. Mar Biol 129:531-539

Sala E, Ballesteros E (1997) Partitioning of space and food resources by three fish of the genus Diplodus (Sparidae) in a Mediterranean rocky infralittoral ecosystem. Mar Ecol Prog Ser 152:273-283

Sala E, Zabala M (1996) Fish predation and the structure of sea urchin Paracentrotus lividus populations in the NW Mediterranean. Mar Ecol Prog Ser 140:71-81

Sala E, Boudouresque CF, Harmelin-Vivien M (1998) Fishing, trophic cascades, and the structure of algal assemblages: evaluation of an old but untested paradigm. Oikos 82: 425-439

Steneck RS (1998) Human influences on coastal ecosystems: Does over fishing create trophic cascades? Trends Ecol

Editorial responsibility: Tim McClanahan, Mombasa, Kenya
Evol 13:429-430

Tegner MJ, Dayton PK (2000) Ecosystem effects of fishing in kelp forest communities. ICES J Mar Sci 57:579-589

Tuya F, Boyra A, Sánchez-Jerez P, Barbera C, Haroun RJ (2004) Relationships between rocky-reef fish assemblages, the sea urchin Diadema antillarum and macroalgae throughout the Canarian Archipelago. Mar Ecol Prog Ser 278:157-169

Tuya F, Sánchez-Jerez P, Haroun RJ (2006) Populations of inshore serranids across the Canarian Archipelago: relationships with human pressure and implications for conservation. Biol Conserv 128:13-24

Walker BH (1992) Biodiversity and ecological redundancy. Conserv Biol 6:18-23

Worm B, Barbier EB, Beaumont N, Duffy JE and others (2006) Impacts of biodiversity loss on ocean ecosystem services. Science 314:787-790

Submitted: March 29, 2010; Accepted: June 9, 2010

Proofs received from author(s): August 14, 2010 